\title{
A fossil dung midge in Mexican amber (Diptera: Scatopsidae)
}

\author{
André Nel and David Coty
}

\begin{abstract}
The first fossil representative of Psectrosciarinae, Psectrosciara fossilis sp. nov., is described and figured from the Late Oligocene to Middle Miocene Mexican amber of Totolapa. It belongs to the brunnescens-group sensu Cook, but differs from all the modern representatives in the presence of two foliaceous lobes at the extremity of the gonostyles, base of M1 clearly visible, and 10-segmented antennae.
\end{abstract}

André Nel. Institut de Systématique, Évolution, Biodiversité, ISYEB - UMR 7205 - CNRS, MNHN, UPMC, EPHE, Muséum national d'Histoire naturelle, Sorbonne Universités, 57 rue Cuvier, CP 50, Entomologie, F75005, Paris, France. anel@mnhn.fr

David Coty. Institut de Systématique, Évolution, Biodiversité, ISYEB - UMR 7205 - CNRS, MNHN, UPMC, EPHE, Muséum national d'Histoire naturelle, Sorbonne Universités, 57 rue Cuvier, CP 50, Entomologie, F75005, Paris, France.coty.david@gmail.com

Keywords: Insecta; Diptera; Scatopsidae; Psectrosciarinae; first fossil record; Mexican amber

Submission: 25 January 2016. Acceptance: 24 June 2016

\section{INTRODUCTION}

The Scatopsidae are small to minute dark flies found worldwide, but with a poorly known fossil record (see Amorim, 1998; Nel and Prokop, 2004; Fate et al., 2013). The family is divided into four subfamilies, Aspistinae Rondani, 1840, Ectaetiinae Enderlein, 1936, Psectrosciarinae Cook, 1963, and Scatopsinae Newman, 1834 (Amorim, 1994; Huerta and Hribar, 2015). Since now, no fossil is recorded for the small subfamily Psectrosciarinae that comprises only the two genera Psectrosciara and Anapausis. Nevertheless Amorim and Haenni (1992) made the hypothesis that the origin of the scatopsiformis-group of species of Psectrosciara is somewhat earlier than the Lower Jurassic, on the basis of biogeographic considerations. Thus it was surprising that this subfamily had no known fossil representative. Here we describe the first fossil $P$ sectrosciara from the Miocene Mexican amber.

\section{MATERIAL AND METHODS}

Totolapa is located in the central depression of Chiapas, $70 \mathrm{~km}$ at the south-east of Tuxtla Gutierrez, the capital of Chiapas State. Salt River mine, exploited since 2007 , is $1 \mathrm{~km}$ north of Totolapa, on the banks of the Salt River. As a complete geological study is lacking, we are therefore in the incapacity to give a precise age and consider that the

http://zoobank.org/FE9FB15D-E545-45FD-B14A-1D2B4E6F5957

Nel, André and Coty, David. 2016. A fossil dung midge in Mexican amber (Diptera: Scatopsidae). Palaeontologia Electronica 19.2.22A: $1-6$

palaeo-electronica.org/content/2016/1527-fossil-scatopsidae-in-amber 

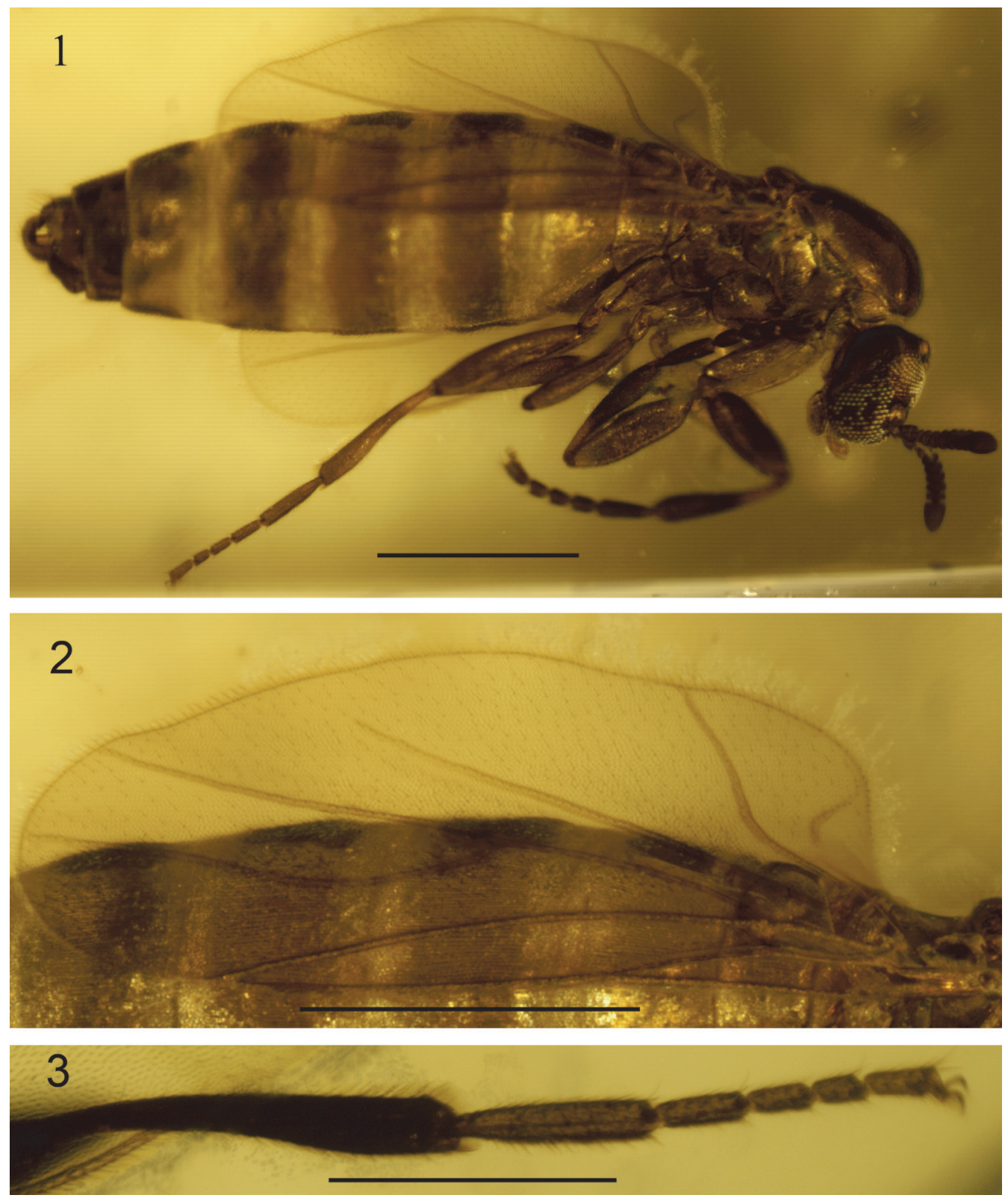

FIGURE 1. Psectrosciara fossilis sp. nov., holotype MNHN.F.A57265. 1, general habitus; 2 , wing; 3 , hind leg. Scale bars represent $0.5 \mathrm{~mm}(1), 0.5 \mathrm{~mm}(2), 0.25 \mathrm{~mm}(3)$.

amber from Salt River Mine must be from Late Oligocene to Middle Miocene (25-15 Ma. see Coty et al., 2014 for a synthesis on this problem).

The original external surface of the amber piece has been removed by polishing; final lustration was done using diatomite powder. The specimen was examined under Nikon SZ10 and Olympus SZX9 stereomicroscopes. Photos were taken with an Olympus E-3 digital camera. Several digital pictures were reconstructed using Helicon Focus software.

\section{SYSTEMATIC PALAEONTOLOGY}

Order DIPTERA Linnaeus, 1758

Family SCATOPSIDAE Newman, 1834

Subfamily PSECTROSCIARINAE Cook, 1963

Genus PSECTROSCIARA Kieffer in Enderlein, 1911

Type species. Psectrosciara mahensis Kieffer, 1912

Psectrosciara fossilis sp. nov.

(Figures 1-3)

zoobank.org/EB43CB40-EE54-4AB4-8FCE-C7AB481FA1FA 

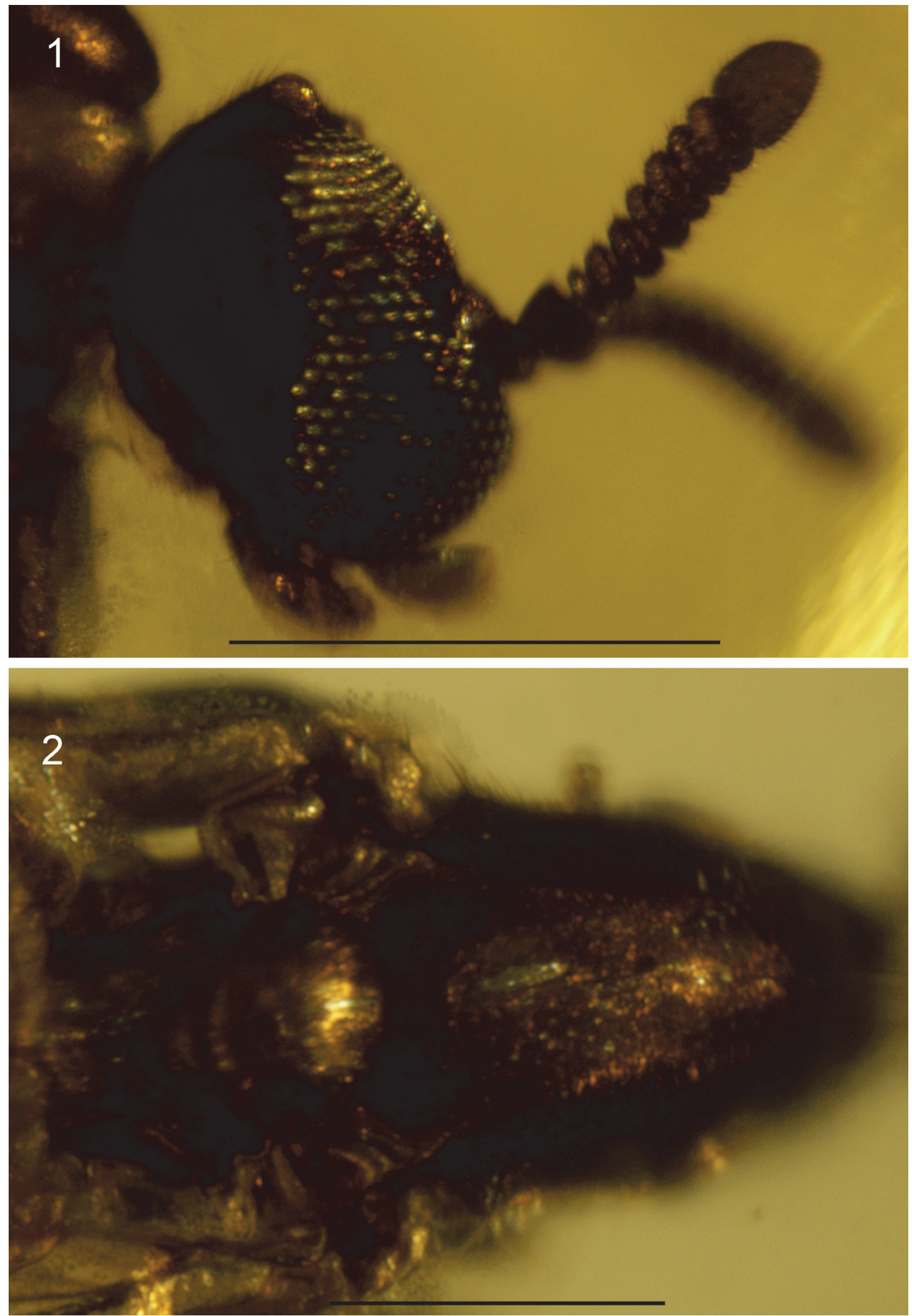

FIGURE 2. Psectrosciara fossilis sp. nov., holotype MNHN.F.A57265. 1, head; 2, dorsal view of thorax. Scale bars represent $0.5 \mathrm{~mm}(1)$ and $0.25 \mathrm{~mm}(2)$. 

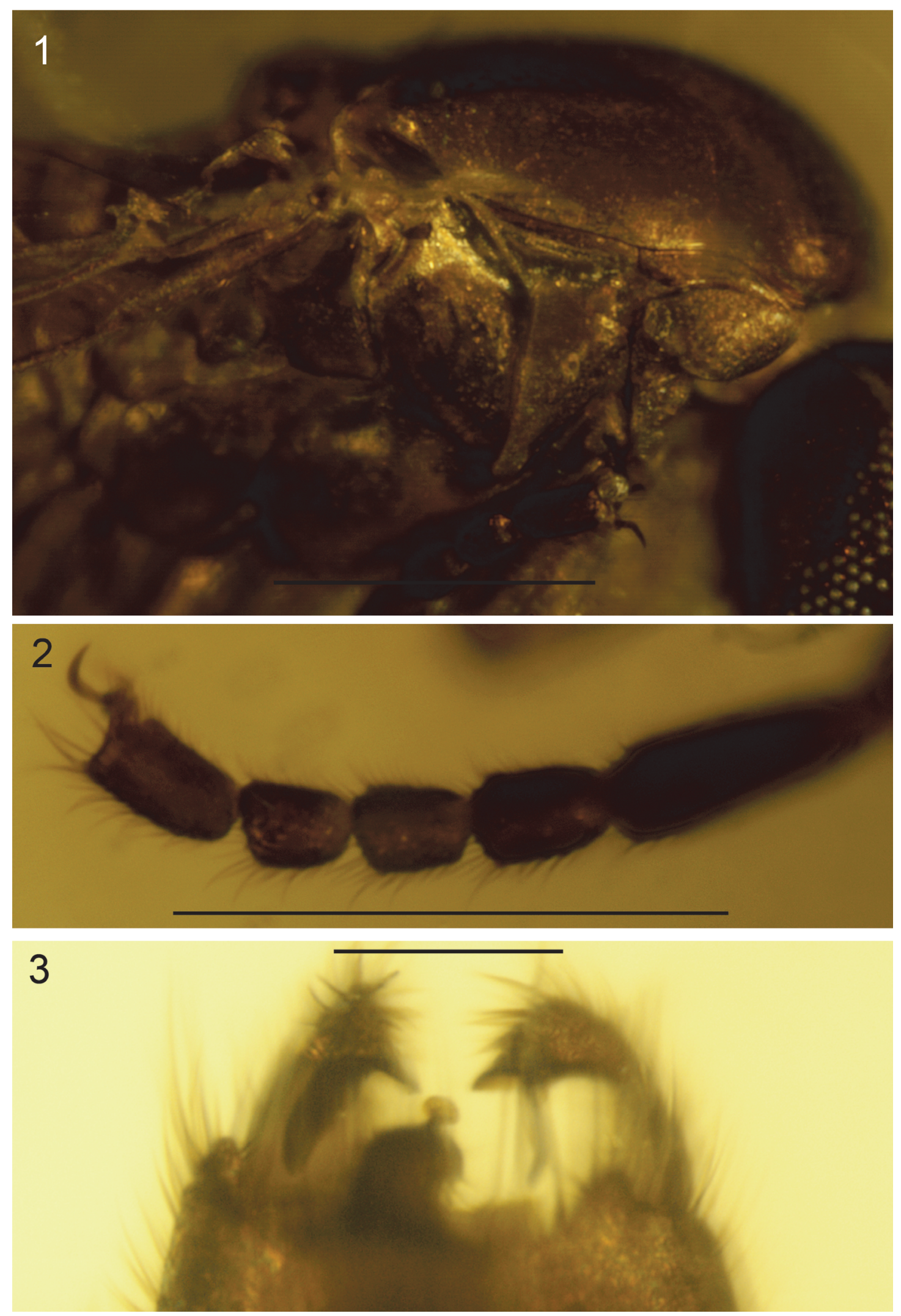

FIGURE 3. Psectrosciara fossilis sp. nov., holotype MNHN.F.A57265. 1, lateral view of thorax; 2 , fore tarsi; 3, genitalia. Scale bars represent $0.5 \mathrm{~mm}(1), 0.25 \mathrm{~mm}(2), 0.01 \mathrm{~mm}(3)$. 
Etymology. Named after the fact that it is the first fossil record of the genus.

Holotype. MNHN.F.A57265 stored at the MNHN, Paris.

Type horizon. Late Oligocene-Middle Miocene, Type locality. Salt River mine, Totolapa, Chiapas, Mexico.

Diagnosis. Male characters only. Presence of two foliaceous lobes at the extremity of the gonostyles; base of M1 clearly visible; 10-segmented antennae.

Description. Body $2.7 \mathrm{~mm}$ long; head $0.25 \mathrm{~mm}$ long, dark; antennae with 10 segments, the first flagellomere very short, last flagellomere bulletshaped; eyes holoptic, lateral margin oblique. Thorax compressed laterally, brown; mesonotum bare, uniformly light brown; scutellum and metanotum light brown. Wing length $1.44 \mathrm{~mm}$, width $0.61 \mathrm{~mm}$; $\mathrm{C}$ extending $82 \%$ of wing length, Sc short; macrotrichia on all veins and on membrane posteriorly to vein $R 4+5$; membrane covered with microtrichia; all veins brownish, posterior ones less so but clearly contrasting with wing membrane; base of vein $\mathrm{M} 1$ more diffuse than other veins but still clearly visible; base of $\mathrm{M}$ clearly visible; vein $\mathrm{CuA1}$ not reaching wing margin; A1 strongly curved. Halter with knob and stem bare. Legs brown; fore coxa long, almost as long as femur; tibiae and tarsi not armed with stout, short spine-like setae but tibiae with very short ventro-apical spines; fore tibia with distal half distinctly dilated; mid and hind tibiae gradually dilated in all its length; hind 1st tarsomere longer than other tarsomeres.

Abdomen brown, cylindrical, long, distinctly overpassing tip of wings. Tergite 1 short, wider than long; tergite 2 divided in a small anterior sclerite and a larger posterior sclerite; tergites 3-5 rectangular, longer than wide; tergite 5 somewhat wider; tergite 6 quadrate; tergite 7 somewhat wider than long; tergite 8 short, projecting latero-posteriorly, with very long hairs and a pair of dorsolateral spiracles, well distant each other; tergites 1-8 with an anterior slight emargination, sternite 7 entire.

Genitalia. Epandrium bottle-shaped, with a preapical strangulation; gonocoxites well developed, long, with long hairs; gonostyles very long and narrow, with two leaf-like apical expansions, curved upwards and inwards, with long hairs.

\section{DISCUSSION}

Following the key to the Nearctic scatopsid genera of Cook (1981) and the revision of Anapausis by Amorim and Balbi (2006), Psectrosciara fossilis sp. nov. falls in the genus Psectrosciara
(Psectrosciarini Cook, 1963) for the characters: body elongate and compressed laterally, scutum without a U-shaped ridge; fore tibia not produced apically; C not swollen at junction with R4+5; eyes holoptic; wing with false vein absent; wing membrane and veins with obvious setae; base of $M$, arising at base of R4+5 (Psectrosciarinae Cook, 1963); R4+5 long, extending beyond middle of wing, not strongly curved, intersecting $C$ at an acute angle; presence of vein A1; stem of halter without setae, anterior spiracle situated on anepisternum, unlike in Anapausis Enderlein, 1912 (see Amorim and Balbi, 2006, p. 4). Lastly the spiracles of tergite 8 are well distant each other (not near each other mesally on the tergite, unlike in Anapausis (Anapausini Amorim, 1994) (Amorim, 1994, p. 110).

The tibiae and tarsi not armed with stout, short spine-like setae, sternite 7 not divided into two lobes, and long gonocoxites are characters of the brunnescens-group as defined by Cook (1958, p. 589) (see also Amorim and Haenni, 1992; Huerta and Hribar, 2015). Amorim (1982) confirmed the monophyly of the two brunnescens- and the scatopsiformis-groups of species within Psectrosciara. The brunnescens-group is widespread from Southeast Asia to North America. An obvious difference between our fossil and the modern representatives of the genus Psectrosciara is the vein M1 complete, not interrupted at the base, which is probably a plesiomorphy. Cook (1958, p. 588) indicated that few modern species, e.g. P. brunnescens (Brunetti, 1911) and $P$. forcipata Cook, 1958, have a 'faint connection with M'. Also P. ampullacea CarlesTolrá, 2008 has a base of M1 still visible, even if it is faint (Carles-Tolrá, 2008, fig. 3).

After Cook $(1958,1978)$ and Haenni (1990, pers. comm.), the brunnescens-group comprises the following species: $P$. brunnescens (Brunetti, 1911) (Ceylon, Seychelles Islands); P. Iuzonensis Edwards, 1929 (Philippine Islands); P. brevicornis Johannsen, 1946 (Guam); P. forcipata Cook, 1958 (California); P. discata Cook, 1958 (California); P. oregonensis Cook, 1958 (Oregon); P. bakeri Cook, 1958 (California); P. brevistylis Cook, 1958 (Iran); P. stonei Cook, 1958 (Texas); P. arnaudi Cook, 1978 (Mexico); P. africana Cook, 1965 (Africa); P. asklepios Haenni, 1990 (Greece); and P. ampullacea Carles-Tolrá, 2008 (Spain). P. fossilis differs from all these species except $P$. stonei and $P$. brevicornis in the presence of two foliaceous lobes at the extremity of the gonostyles. $P$. africana has a R4+5 distinctly longer than in $P$. fossilis (Cook, 1965). P. stonei has the base of M1 absent, unlike 
P. fossilis and P. brevicornis (Cook, 1958). P. arnaudi has M1 scarcely connected to the base of M, unlike P. fossilis (Cook, 1978). P. fossilis has 10segmented antennae instead of nine-segmented in $P$. brevicornis. P. asklepios has broadly clubshaped gonostyles but differs from $P$. fossilis in the 10-segmented antennae and the basal part of M1 very faint (Haenni, 1990).

\section{ACKNOWLEDGEMENTS}

We sincerely thanks J.-P. Haenni and an anonymous referee for the useful comments on the first version of the paper. We would like to thank M. Ramirez and $\mathrm{H}$. Ramirez, owners and miners of Salt River Mine, Totolapa, and their whole family, for their great help in David Coty field research.

\section{REFERENCES}

Amorim, D. de S. 1982. Sistemática filogenética dos Scatopsidae (Diptera: Oligoneura: Bibionomorpha). Unpublished PhD Thesis, Universidade de Sao Paulo, Brazil.

Amorim, D. de S. 1994. A new suprageneric classification of the Scatopsidae (Diptera: Psychodomorpha). Iheringia, serie Zoologia, 77: 107-112.

Amorim, D. de S. 1998. Amber fossil Scatopsidae 1. Considerations on described taxa, Procolobostema roseni $\mathrm{n}$. sp. from Dominican amber, and the position of Procolobostema in the family. American Museum Novitates, 3227:1-17.

Amorim, D. de S. and Balbi, M.I.P.A. 2006. A review of Anapausis Enderlein (Diptera: Scatopsidae) in the Neotropical region, with four new species and comments on the phylogeny of the genus. Zootaxa, 1300:1-29.

Amorim, D. de S. and Haenni, J.-P. 1992. A new species of Psectrosciara Kieffer from east Siberia belonging to the scatopsiformis-group of species (Diptera, Scatopsidae). Mitteilungen der Schweizerischen Entomologischen Gesellschaft, 65:363-367.

Carles-Tolrá, M. 2008. Psectrosciara ampullacea sp. n.: a new scatopsid species from Spain (Diptera: Scatopsidae). Boletín Sociedad Entomológica Aragonesa, 42:85-87.

Cook, E.F. 1958. A contribution toward a monograph of the Scatopsidae (Diptera). Part 7. The genus Psectrosciara Kieffer. Annals of the Entomological Society of America, 51:587-595.

Cook, E.F. 1963. Guide to the insects of Connecticut, pt. 6. The Diptera or true flies, fasc. 8. Family Scatopsi- dae. Bulletin of the Geological Survey of the Connecticut, 93:1-37.

Cook, E.F. 1965. Diptera (Nematocera): Scatopsidae. South African Animal Life, 11:469-481.

Cook, E.F. 1978. A new genus and five new species of Scatopsidae from California, Mexico, El Salvador and Peru (Diptera). The Pan-Pacific Entomologist, 54:31-37.

Cook, E.F. 1981. Scatopsidae, pp. 313-319. In McAlpine, J.F., Peterson, B.V., Shewell, G.E., Teskey, H.J., Vockeroth, J.R., and Wood, D.M. (eds.), Manual of Nearctic Diptera, 1, Biosystematic Research Institute, Ottawa, Ontario.

Coty, D., Aria, C., Garrouste, R., Wils, P., Legendre, F., and Nel, A., 2014. The first ant-termite syninclusion in amber with CT-scan analysis of taphonomy. PLoS ONE, 9 (8), e104410. doi:10.1371/ journal.pone.0104410.

Enderlein, G. 1911. Die phyletischen Beziehungen der Lycoriden (Sciariden) zu den Fungivoriden (Mycetophiliden) und Itonididen (Cecidomyiiden) und ihre systematische Gliederung. Archiv für Naturgeschichten, 77:116-201.

Enderlein, G. 1936. Diptera (Zweiflügler). Tierwelt Mitteleuropas (6: Insekten), 3:1-259.

Fate, C., Perrichot, V., and Nel, A. 2013. A Mid Cretaceous representative of the modern scatopsid genus Ectaetia (Diptera: Scatopsidae: Ectaetiinae). Zootaxa, 3686:396-400.

Haenni, J.-P. 1990. First European record of Psectrosciara Kieffer, with description of a new species from Greece (Diptera, Scatopsidae). Mitteilungen der Schweizerischen Entomologischen Gesellschaft, 63:255-257.

Huerta, H. and Hribar, L.J. 2015. Description of a new species of the genus Psectrosciara and a new record of Parascatopse sonorensis (Diptera: Scatopsidae) From Florida. Journal of Insect Science, 15:1-5.

Linnaeus, C. von 1758. Systema Naturae per regna tria naturae secundum classes, ordines, genera, species cum characteribus, differentiis, synonymis, locis. Ed. decima reformata. Holmiae, Laur. Salvii.

Nel, A. and Prokop, J. 2004. New Paleogene Scatopsidae (Diptera: Nematocera) in amber from Czech Republic and France. Acta Societatis Zoologicae Bohemicae, 68:91-98.

Newman, E. 1834. Attempted division of the British insects into natural orders. Entomological Magazine, 2:379-431.

Rondani, C. 1840. Sopra alcuni nuovi generi di insetti ditteri per servire alia Dipterologia Italiana., Donati, Parma. 